\title{
Integration of Information \& Communication Technology in the Teaching of Sport, Physical \& Health Education for \\ Sustainable Development in North-Eastern Nigeria
}

\author{
Rajah Balami, Sunday Malgwi \& Omeje Chigozie \\ Physical and Health Education Department \\ School of Sciences \\ Federal College of Education Yola, Nigeria \\ DOI: $10.31364 / S C I R J / v 8 . i 5.2020 . P 0520773$ \\ http://dx.doi.org/10.31364/SCIRJ/v8.i5.2020.P0520773
}

\section{Introduction}

Vision defines the desired or intended future state of an organization or enterprise in terms of its fundamental objectives and/or strategic direction. Vision is a long term view, sometimes describing how the organization would like the world in which it operates to be (This Day 2016). The dream of Nigeria Federal Government is to be among the top 20 leading economics in the world by the year 20-20-20 as the importance and popularity of sport and physical and health education in our contemporary affairs have made the teaching and coaching of the discipline an attractive and respectable phenomenon. The awareness that physical and health education and sports are integral aspect of general education has placed greater demands and responsibilities on the shoulders of its professionals and stakeholders. Today, the need for physical and health education teachers to be well versed in multiple job related skills along with teaching has become even more apparent. Given the much emphasis for enhanced professional integrity, performance and recognition in the teaching and practice of physical and health education and sports (Ojeme, 2016 and Oduyale 2017) expressed the need for research and development in science and technology in Nigeria by the professionals in the field. Physical and health Educators at Secondary and Tertiary Levels need to be very knowledgeable and competent in a variety of skills so as to effectively grapple with the multiplicity of newer concepts and application of modern scientific technological advances to sports and physical and health education situations.

Awosike (2015) stated that the amazing world of improved Information and Communication Technology (ICT) process is dramatically improving productivity and quality of teaching and learning. It is proper that physical and health education teachers and other users of (ICT) must have technological background so as to make use of technologically based assets which will enable them collect, collate and disseminate information in timely basis. In the area of physical and health education and sports, there is apparent observation that much emphasis and consideration has not been given to the teaching and learning of the discipline with the modern (ICT). It is therefore necessary to review and acquaint physical and health educators with the knowledge of current advances in (ICT) for appropriate education and re-education of prospective professional on training and practicing which has become necessary.

\section{The Concept of Information and Communication Technology (ICT)}

Technology is derived from Greek word 'techne' which means art or craft. Technology refers to knowledge we possess concerning ways of doing things as how we design, produce, distribute and sell goods and services. It involves the use of scientific ideas in creating things or solving problems in the society. There is hardly any human activity where technology has not 
made an in-road. Mules (2017) defined technology as a planned systematic method of working to achieve planned outcomes. He further elucidated that technology involves systems, organizational patterns, procedures, and various forms of analysis, research and development and that Technology is indeed applied science.

Technology therefore, embrace with its scope great arrays of ideas, some of which were explored to apparent limits; and others in the form of posted problems and emergent issues. Technology therefore, is an important tool in educational systems, be it primary, secondary or tertiary. Suleiman (2017) opined that technology can be applied to various levels of educational practice.

Adegbesan \& Ekpo (2017) stated that Information Communication Technology is simply the tools and methods used for the identification, organization and manipulation of facts known as data. It refers to knowledge and ideas which are provided in order to increase awareness.

The appreciation of the importance of (ICT) as a vital resource for successful teaching/coaching physical and health education and sport is a new phenomenon in the developing countries. Ojeme (2016) lamented that the major difference in sport development and performance between developed and developing world is their level of development in information communication technology.

Effort has been made over the years to improve the means of communication and that effort has led to the advent information communication technology, which has created computer and allied networks with a consistent and efficient means access the collective knowledge electronically. Obviously, there is need for a more extensive application of the new technologies to teaching and learning of physical and health education and sports in our schools and colleges. In view of Umeasigbu, (2015), information communication technology should encompass application of modern skills and techniques through the manipulation of machines, so as to meet the modern requirement for educational growth of teachers.

\section{Role of Information Communication Technology in Teaching Physical and Health Education and Sport}

Education in Nigeria today has reached the stage where some radical measures need to be taken on effective teaching and learning in view of the under achievement of students in the classroom and in the public examination (Ibode 2018). Admittedly, the scientific understanding of Physical and Health Education and sport has increased dramatically in recent times than some decades ago. Much of information that has been sought traditionally by going to the library, resource persons or school, is now made available through Information Communication Technology facilities such as the internet.

Uwa \& Agbanusi (2015) \& Umeifekwem (2015) listed the following as some of the available (ICT) facilities that can be integrated in the teaching/ learning of physical and health education and sport.

- Systematized feedback or video feedback

- Computer based operation network

- Internet/world wide web sites

- Compact disc with read only memory

- Camcorders and Digital Camera:

- Computer Assisted Instruction. (Power Point Presentation)

www.scirj.org

(C) 2020, Scientific Research Journal

http://dx.doi.org/10.31364/SCIRJ/v8.i5.2020.P0520773

This publication is licensed under Creative Commons Attribution CC BY. 
- Digital physical Education and sports machines/Equipment

- Television and Radio

These (ICT) devices can be used in a variety of ways to enhance the teaching and learning of physical and health education and sports. Using (ICT) device to enhance and improve the teaching of physical and health education and sport are now in vogue in many universities in Nigeria where lectures are provided with computers, CD- ROM and Internet connectivity. Modern teachers today know that the computer which is considered as an essential element in societal paradigm, is needed for modern instruction in teaching of physical and health education, sport science and sport management.

1. Hughes, Franks \& Nagelkerke (2016) advocated the use and integration of recent advances such as computers and video feedback devices to bring about the desired objective feedback which is vital in teaching/learning process especially in PHE.

2. Hinson (2015) noted that physical and health education teachers use the internet to take part in newsgroups that address the needs and interests related to physical and health education and teaching. Siedentop (2017) maintained that telecommunication can be utilized to enhance instruction and expand the students'experience in physical education.

3. In similar vein, Everhert and Turner (2018) observed that students and teachers use video recorders to analyse and improve their learning. Teachers also use it for their classroom and hall instruction. Internet is the web is currently used by professional sport teams and federations in ways that are amazing.

4. A number of software programmes were available for use in physical education and sports. Also there are arrays of audiovisual, materials which are devices that deal with hard and software, radio, television and other electronic devices/real objects which are available to physical and health education professional for use in the classrooms.

5. Films, graphics materials, programmed instructions and diagrams are also information devices that assist the teacher in presenting more effective teaching.

\section{Application Areas of Computer Devices in Physical and Health Education and Sport}

1. In football goal keeping

2. Technological impact in health,

3. In physical and Health Education

4. In Recreation

5. Dance Education

6. Research

7. Classroom Teaching and

8. Distance Education

Classroom Utilization of Computer Devices/Specialized Software for Physical and Health Education and Sport.

- It provide classroom instructions

www.scirj.org

(C) 2020, Scientific Research Journal

http://dx.doi.org/10.31364/SCIRJ/v8.i5.2020.P0520773

This publication is licensed under Creative Commons Attribution CC BY. 
- Variety of software programs for physical sports use.

- Commercial and shake-wane programs used for track grading.

- Students athletic performance and fitness

- It conducts health assessments via variety of digital computerized devices

- Provide simulative of diseases and

- Monitor research projects

\section{Other Software being developed includes}

- In the kinesiology classroom students can observe and listen to the mechanics of movement in slow motion and play over those parts that do not understand.

- In physical education classroom movement of muscles and speed of the heart and systems can be view and motored.

- In scoring and determining the wining on Penalty/goal scores in a football game.

Problem advocating is one thing, practicability is another. Nigerian Unsteady economy, couple with the high cost of importing technological equipment have become a cog in the wheel of progress. Consequently, many schools and colleges in Nigeria cannot and these devices for effective teaching. Lectures in many Nigeria universities do not have access to the internet for use in their lectures. Many of them even, are not computer. Literacy on information communication technology has not assumed a serious dimension in many Nigerians schools and colleges and this is a hindrance toward gain education subsequent.

\section{Conclusion}

Information technology devices are rapidly becoming a necessity for sports, athletes', coaches and physical and health education teachers at whatever levels in teaching hierarchy. The integration of information technology in the teaching and learning of physical and health education and sport will be a significant development. Indeed the acquisition of necessary competencies in the use of soft should be a sure way of reengineering Nigeria's sport delivery systems so as to cope effectively with the challenges of the millennium development goals.

\section{Recommendation}

The following are some recommendations made;

1. One of the ways forward is for the physical and health education professionals, researchers, coaches and students to have the technological know-how in order to make use of information technologically based assets in effective teaching of both theories and practices of physical and health education.

2. Physical and health education teachers and students need to be computer literate and also literate in information technology.

3. Also with envisaged improvement in Nigeria's economy, government should relax import duties in science and technology equipment. This will bring down the cost to within the reach of institutions. 
4. Colleges and Universities should be equipped with ICT devices that can aid the teaching and learning of Physical and health education in Nigeria.

5. Physical and health educators, coaches, sports physiologist should be encourage to use power point presentation during lectures, workshop or seminaries for the benefit of athletes and students

\section{References}

Adegbesan, O.A., \& Ekpo, G.A. (2017). The Role of Information Technology in Sports and Physical Education in Igbanugo, Ogundele and Abass (ed) Multidiscipline Approach to Human Kinetics and Health Education Ibadan, Codat Publications.

Awosika, Yomi (2015) Use of New Technology in the Teaching of Physical \& Health Education. In Okuneye (Ed) STAN- PHE Book of Proceedings 6 National Workshops 12-23

Everhert, B.D \& Turner, B. (2018). Computer Feedback for Improved Teacher Training. Journal of Physical Education, Recreation and Dance (66) 9

Hunson, C. (2015). Pulse Lciwer; A Hear Physiology Programme for Children. Journal of Physical Education, Recreation and Dance (65) 1-9

Hughes, D.I, Franks. I.M. \& Nae1ker1ce, P. (2016). A Video System for Qualitative Motion Analysis in Competitive Sport. Journal of Human Movement Studies (17) 212-227.

Thode, F (2018). Relative Effects of Computer-Assisted and Videotape Instructional Modes on Students.

This Day (2016). Nigeria Vision 20:2020 Achievable Through Science, Technology.

Mules, M. B. (2017) Technological Innovations in Education. New York: Columba University Bureau of Publications.

Ocluyale, A. T. (2017) Innovations in Nigeria Physical Educations, In Igbanugo (3rd Ed) Proceedings of 11CHPER.SD. African Regional Conference 47-50

Ojeme, E. O. (2016) Physical Education Curriculum Perspective for 6-3-3-4 System of Education in Nigeria. Physical and Health Education and Recreation Journal. 5(1) 52-67

Siedentop, D. (2017) Introduction to Physical Education Fitness and Sport (4th Ed). Mayfield. Mountain View. C.A.

Suleiman, E.T (2017). Understanding Technology Adaptation; Theory and Future direction and Informal Learning. Review of Educational Research 79 (2), 625-649; Dol: 3102/0034654308325896

Uwa \& Agbanusi (2015) The Role, Current Practice and Potential for Use of Information and Communications Technology in Physical Education in Nigerian Secondary Schools: A Pilot Study, Lagos State Educational Research Association Conference, University of Lagos Unilag, September $14^{\text {th }}-17,2013$

Umeifekwem (2015) Body and Mind: A Report on the Use of ICT in PE. Coventry: BECTa. Available Online at http://www.becta.org.uk/corporate/publications/documents/ict_in_pe.pdf (accessed 15/10/16). 